\title{
Cryptocurrency: Towards Regulating the Unruly Enigma of Fintech in Nigeria and South Africa
}

\section{P.E.R}

Pioneer in peer-reviewed, open access online law publications

Author

Festus O Ukwueze

Affiliation

University of Nigeria

Email

festus.ukwueze@unn.edu.ng

Date Submission

17 April 2021

Date Revised

28 June 2021

Date Accepted

30 June 2021

Date published

20 August 2021

Editor Dr TV Warikandwa

How to cite this article

Ukwueze FO "Cryptocurrency:

Towards Regulating the Unruly Enigma of Fintech in Nigeria and South Africa" PER / PELJ 2021(24)

- DOI

http://dx.doi.org/10.17159/1727$3781 / 2021 / v 24 i 0 a 10743$

\section{Copyright}

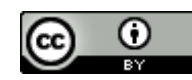

DOI

http://dx.doi.org/10.17159/1727-

3781/2021/v24i0a10743

\begin{abstract}
One of the most modern inventions of financial technology (FinTech) since after the global financial crisis of 2008 is the crypto or virtual currency/asset. Since the creation of the first cryptocurrency, the Bitcoin, in 2009, it is estimated that over five thousand variants of the Bitcoin and other cryptocurrencies have emerged. Virtual currencies have become widespread across the globe but their legal status and uses in various countries have remained uncertain. They have been variously classified as currencies, securities, properties, assets, commodities and tokens, and used as means of exchange but are not legally recognised as legal tender. In many jurisdictions their emergence was greeted with scepticism and express or tacit rejection by financial and securities markets regulators, but over time, owing to their increasing popularity, characteristics, positive and negative potentials, there has been a gradual shift towards their formal recognition and regulation. Regulatory authorities in many countries are now grappling with designing appropriate policy and regulatory framework for the crypto phenomenon. This paper interrogates the current legal status and efforts to regulate cryptocurrencies in two leading African nations, Nigeria and South Africa, and highlights the challenges of designing an appropriate regulatory framework for this enigmatic technology. The paper adopts the doctrinal legal research methodology, employing the descriptive, analytical, and comparative approaches. It follows a structured review and analysis of relevant extant legislation on currencies and securities in the countries to ascertain whether they cover cryptocurrencies. It then compares the current position of the law on the subject in the two countries. Bearing in mind that it may not be possible to totally ban dealing in cryptocurrencies, the paper concludes that regulation has become imperative. Drawing from the position on the subject in more developed nations, the United States of America (US) and the European Union (EU), this paper proposes a model of regulation of virtual currency not only for Nigeria and South Africa but also for other African countries.
\end{abstract}

\section{Keywords}

Cryptocurrencies; virtual currencies; digital assets; FinTech; blockchain; regulation. 


\section{Introduction}

Crypto or virtual currencies have become prevalent and are being used for diverse purposes around the world. They create "monies" and "securities" without central banks and security commissions, are traded freely in most countries, and trade in them has become a multibillion dollar industry, ${ }^{1}$ with an estimated total market capitalisation of over $\$ 342$ billion and a daily trading volume of over $\$ 87$ billion as at 30 September $2020 .^{2}$ The digitally secure and anonymous platforms in which they operate enable transactions to be performed without the involvement of intermediaries such as commercial banks, other financial institutions or securities commissions. Cryptocurrencies evoke mixed reactions from commentators. On the one hand, their critics perceive them as "bubble", "scam", "evil", ${ }^{3}$ fraud, insecure, extremely volatile, ${ }^{4}$ "unsustainable"5 and having a propensity to relate to money laundering, the financing of terrorism, and other nefarious activities. ${ }^{6}$ On the other hand, their advocates think they are more secure than equities and make for financial inclusion as they benefit the "disenfranchised" (that is, people living in places banks cannot or will not serve) and predict that they will ultimately replace money. ${ }^{7}$ It could also be argued that cryptocurrencies provide a certain level of privacy and anonymity in transactions that fiat currencies cannot do.

While financial and securities market authorities are grappling with how to regulate cryptocurrencies, massive "mining" (creation) of crypto coins continues on a daily basis. The increasing popularity of cryptocurrencies and its varied uses pose a range of policy and regulatory challenges, including the need to review and apply extant rules of financial oversight, consumer protection and tax administration. The question is: can this enigmatic financial technology be effectively regulated, and how? In seeking to provide answers to these nagging questions, this paper examines the current legal status as well as the legality of the use of cryptocurrencies in

Festus O Ukwueze. LLB Hons LLM PhD (Nig). Senior Lecturer, Department of Commercial and Corporate Law, Faculty of Law, University of Nigeria. E-mail: festus.ukwueze@unn.edu.ng. Orcid: https://orcid.org/0000-0003-0293-5021.

World Bank Cryptocurrencies and Blockchains 22.

CoinMarketCap 2020 https://coinmarketcap.com/charts.

Krugman New York Times 23.

Franco Understanding Bitcoin 33.

Henry and Irrera 2017 https://www.reuters.com/article/us-usa-banks-conferencejpmorgan/jpmorgans-dimon-says-bitcoin-is-a-fraud-idUSKCN1BN2KP; Imbert 2017 https://www.cnbc.com/2017/09/12/jpmorgan-ceojamie-dimon-raises-flag-ontrading-revenue-sees-20-percent-fall-for-the-third-quarter.html; Malmo https://motherboard.vice.com/en_us/article/ae3p7e/bitcoin-is-unsustainable 1. 2015 Clements 2018 MBELR 79.

Rooney 2018 https://www.cnbc.com/2018/03/15/peter-thiel-is-betting-on-bitcoin-tobe-the-online-equivalent-to-gold.html. 
Nigeria and South Africa, the two leading economies in Africa. ${ }^{8}$ The paper adopts the doctrinal research methodology and employs the descriptive, analytical and comparative approaches involving the structured review and analysis of relevant extant legislation on currencies and securities in the two countries to ascertain whether cryptocurrencies are legal under their existing laws, and whether they can be covered by such laws as were enacted before their invention. The paper also highlights the challenges that financial and securities authorities face in regulating cryptocurrencies as a result of their volatility and diverse applications. Drawing from the positions in advanced jurisdictions, such as the European Union (EU) and the United States of America (US), it proposes a model of regulation, not only for Nigeria and South Africa but also for other African countries.

The paper is divided into seven sections, with this introduction as the first section. The second section is the conceptual clarification, which highlights the meaning, nature, evolution, and forms of cryptocurrencies. The forms, characteristics and uses of cryptocurrencies as well as the challenges faced by monetary and securities authorities in regulating them are identified and discussed. The third and fourth sections discuss the legal status and regulation of cryptocurrencies in Nigeria and South Africa respectively. The fifth section is a comparison of the current efforts to regulate cryptocurrencies in Nigeria and South Africa. The two countries were selected for the study because they are leading economies in Africa ${ }^{9}$ and reportedly have high volumes of cryptocurrency transactions. ${ }^{10}$ The sixth and penultimate section highlights in brief the regulatory models for cryptocurrencies in two developed jurisdiction, the EU and the US, as bases for proposing an appropriate model for Nigeria and South Africa. The seventh and last section concludes the paper with a proposal for an appropriate model for cryptocurrency regulation.

\section{Conceptual clarification}

\subsection{Meaning and nature of cryptocurrency}

Financial technology (FinTech) in its broadest sense connotes the application of technology in the provision of financial services. The term is

According to the International Monetary Fund (IMF) in 2019, Nigeria led the rest of African countries with a GDP of $\$ 444.92$ billion followed by South Africa with a GDP of $\$ 371.30$ billion; see World Population Review 2021 https://worldpopulationreview.com/country-rankings/richest-african-countries.

9 World Population Review 2021 https://worldpopulationreview.com/countryrankings/richest-african-countries.

10 Adesina $2020 \quad$ https://nairametrics.com/2020/05/24/nigerians-love-forcryptocurrencies-on-the-rise-as-it-offers-cheaper-ways-to-transfer-funds; IFWG and CAR WG 2020 https://www.ifwg.co.za/wp-content/uploads/IFWG_CAR_WGPosition_Paper_on_Crypto_Assets.pdf 5-6. 
used to refer to a process as well as entities involved in the process. As a process it is an umbrella term for innovative financial services driven by digital technology. ${ }^{11}$ As an entity, Schueffel asserts that it is "a new financial industry that applies technology to improve financial activities". ${ }^{12}$ Led by innovators, FinTech has become a global phenomenon which is increasingly attracting the attention of financial market regulators. ${ }^{13}$ It is a technologically-enabled financial innovation which has given rise to new business models, applications, processes and products. ${ }^{14}$ FinTech has led to a huge reduction in the use of cash and greatly improved the transmission of money. However, its most recent invention is cryptocurrency (also referred to as virtual currency), which to a great extent seeks to supplant fiat currencies.

A cryptocurrency is a digital representation of value by which transactions can be conducted and verified, and records of the same maintained by a decentralised system using cryptography, ${ }^{15}$ rather than a centralised authority. ${ }^{16}$ Greenberg ${ }^{17}$ describes it as a digital asset designed to work as a medium of exchange wherein individual coin ownership records are stored in a ledger existing in the form of a computerised database using strong cryptography to secure transaction records, to control the creation of additional coins, and to verify the transfer of coin ownership. It is based on cryptology and runs on blockchains, ${ }^{18}$ distributed and decentralised ledgers, where individuals can anonymously transact and maintain records without going through an intermediary. ${ }^{19}$ The recorded transactions are permanent because of the redundancy and reliability of their recording systems. ${ }^{20}$ Unlike coin and paper currencies, cryptocurrencies do not exist in physical form and are not issued by any central authority. They use decentralised control as opposed to the central banking systems used by fiat currencies and exist only in digital and electronic formats in cyberspace.

\footnotetext{
11 Gobble 2018 RTM 56.

12 Schuefell 2016 JIM 45.

13 Mention 2019 RTM 59.

14 Dorfleitner et al "Definition of FinTech" 5

15 Cryptography is a method of protecting information and communications through the use of codes, so that only those for whom the information is intended can read and process it. The prefix "crypt-" means "hidden" or "vault" -- and the suffix "-graphy" stands for "writing." See Richards 2019 https://searchsecurity.techtarget.com/ definition/cryptography 1.

16 Lexico Dictionary 2020 https://www.lexico.com/definition/cryptocurrency 1.

17 Greenberg 2011 https://www.forbes.com/forbes/2011/0509/technology-psilocybinbitcoins-gavin-andresen-crypto-currency.html\#75863f77353e; Polansek 2016 https://www.reuters.com/article/us-cme-group-bitcoin-idUSKCNOXT1G1.

18 Blockchains work by recording transactions into online ledgers that are saved onto separate blocks in different locations, and are inherently difficult to modify.

19 Telegraph Reporters 2018 http://www.telegraph.co.uk/technology/0/cryptocurrency. Galavis 2019 U Miami Int'l \& Comp L Rev 561.
} 
The terms cryptocurrency, virtual currency and digital currency are often used interchangeably. For example, Rose states that digital currency is a form of virtual currency that is electronically created and stored and some digital currencies are cryptocurrencies. ${ }^{21}$ The notions of "crypto" and "virtual" refer to the fact that they are not physical and there is no tangible asset that underlies their existence. However, while conceding that cryptocurrency and virtual currency mean the same thing and any distinction between them is a matter of subtlety, there is a tenuous distinction between the two and digital money, which is sometimes denominated (or linked) to a fiat currency. In the concept of the European Central Bank, virtual currency is "a type of unregulated, digital money, which is issued and usually controlled by its developers, and used and accepted among the members of a specific virtual community".22 To obviate the idea of their being perceived simply as "money" or attaching them to fiat currencies, they are increasingly being referred to as crypto assets, virtual assets or digital assets. These are different from electronic money, which is a legal tender stored or transmitted digitally but denominated in a fiat currency and which derives its value from a sovereign authority.

Nakamoto, the acclaimed founder of Bitcoin, the first cryptocurrency, formulated the philosophy behind it thus:

What is needed is an electronic payment system based on cryptographic proof
instead of trust, allowing any two willing parties to transact directly with each
other without the need for a trusted third party. Transactions that are
computationally impractical to reverse would protect sellers from fraud, and
routine escrow mechanisms could easily be implemented to protect buyers. ${ }^{23}$

Thus, according to Lansky, ${ }^{24}$ to qualify as a cryptocurrency a system must meet six conditions, namely:

(a) no central authority and its state is maintained through distributed consensus;

(b) keeps records and overview of units and their ownership.

(c) determines whether new units can be created, the circumstances of their origin and how to determine the ownership of these new units;

(d) ownership of units can be proved exclusively cryptographically;

\footnotetext{
$21 \quad$ Rose 2015 IBER 617.

22 European Central Bank 2012 https://www.ecb.europa.eu/pub/pdf/other/virtual currencyschemes201210en.pdf 5.

23 Nakamoto 2008 https://bitcoin.org/bitcoin.pdf 1.

$24 \quad$ Lansky 2018 J Syst Integrat 19-31.
} 
(e) allows transactions to be performed in which ownership of the cryptographic units is changed, and a transaction statement can be issued only by an entity proving the current ownership of these units; and

(f) if two different instructions for change of ownership of the same cryptographic units are simultaneously entered, the system performs at most one of them. ${ }^{25}$

\subsection{Evolution, forms and uses of cryptocurrencies}

The genesis of cryptocurrencies is traced to the global financial crisis of 2008. The crisis led to many companies becoming bankrupt, resulting in massive job losses and loss of confidence by investors in the financial system. Investors were looking for new investment opportunities and workers who had lost their jobs were willing to accept more flexible working conditions. This erosion of trust in financial institutions and the financial system arising from the crisis gave rise to the quest for different approaches. Cryptocurrency and blockchains emerged in the wave of technological innovations aimed at facilitating peer-to-peer commerce, financial products individualisation and flexibility in financial methods. The first virtual currency, Bitcoin was created in 2009 by Satoshi Nakamoto, ${ }^{26}$ and is so far reputed to be the most successful cryptocurrency. Since then, well over 5,000 alternative variants of bitcoin and other cryptocurrencies have been created. ${ }^{27}$ They are used for many purposes and have variously been described as "digital money", "digital assets", "securities", etc. ${ }^{28}$ Each cryptocurrency tends to be unique in its own way, but most cryptocurrencies can be grouped under four categories based on their possible uses, ${ }^{29}$ namely as a store of value, as digital money, as utility, and as security tokens.

Store of value cryptocurrencies are those that maintain their purchasing power in the long run. They possess three primary attributes: the ability to preserve or increase future purchasing power; they are cheap to store, and they are liquid. This category of cryptocurrencies aims to solve the challenges of traditional forms of stores of value such as cash, gold, government bonds and stocks, which are usually either costly to buy and

$25 \quad$ Lansky 2018 J Syst Integrat 19.

26 It is unclear to date whether the name refers to an individual or to a group of persons who in 2008 published a paper that is widely believed to have jumpstarted the development of cryptocurrencies. See Antonopoulos Mastering Bitcoin 4.

27 Redman 2020 https://news.bitcoin.com/altcoins-why-over-5000.

28 Clements 2018 MBELR 73-100; Galavis 2019 U Miami Int'I \& Comp L Rev 565-566.

29 Xie 2019 https://medium.com/datadriveninvestor/4-types-of-cryptocurrencies-aframework-to-think-about-cryptoassets-5cf2670fa1d7. 
sell, or erode in purchasing power over time. They are secure and cheap to store, and their prices are completely determined by the dynamics of demand and supply in the market. Examples of cryptocurrencies of this class include Bitcoin, Litecoin and Bitcoin Cash. Digital monies are cryptocurrencies designed for everyday transactions and do not possess long-term purchasing power as their inflation rates are comparable to those of cash. Some digital monies have their values attached to fiat currencies and are affected by movements in the value of such currencies. This makes them unsuitable for long-term investment. They are, however, more costefficient, particularly for sizeable transactions, as they attract flat transaction fees not based on the volume of transaction. They provide a high level of privacy as transactions in them are difficult to track, unlike transactions conducted with fiat money. These attributes also make them popular for illicit dealings such as money laundering, and drug and arms dealing. Cryptocurrencies that fit into this category include Facebook Libra, Dash, Monero, and ZCash. Utility tokens are cryptocurrencies that are used to pay for goods and services on a specific network. This class of cryptocurrencies usually requires users to pay a certain fee for computational power and interactions on the designated network. They offer initial coin offerings (ICOs) to raise money to subsidise the cost and development of the network. New buyers usually come from two streams: financial speculators/investors and actual users. Utility tokens are uncapped; that is, they have the potential for infinite supply, and if the network inflates supply by printing new tokens, no amount of demand will be able to check devaluation. This makes them the most speculative and risky area of cryptocurrency in terms of investment. Examples of this type of cryptocurrencies are Ethereum, Augur and Vechain. Security tokens are digital depictions on blockchains of real-life assets that are subject to securities regulation, such as stocks, equities and real estates. Their benefits include improved liquidity as they can be instantaneously traded on security exchanges. The ownership of tokenised valuable assets can be split into several parts making them easily affordable. This makes them more accessible by investors, who can purchase "parts" of the assets at fractions of the total price. Popular types of this class of cryptocurrencies include C20, Bcap (Blockchain Capital) and Science Blockchain.

\subsection{Challenges to regulating cryptocurrencies}

The legal status of cryptocurrencies and their regulation vary from country to country. In some countries they have explicitly been adopted for trade; in others their use is either banned or restricted, while some countries have yet to take any definite position on them. ${ }^{30}$ The increasing use and

30 An absolute ban on trading in or using cryptocurrencies applies in Algeria, Bolivia, Egypt, Iraq, Morocco, Nepal, Pakistan, and the United Arab Emirates, while an 
characteristics of cryptocurrencies and the ease of their being mis-used requires that they be regulated. According to a statement credited to the former US President, Donald Trump, "Bitcoin and other Cryptocurrencies ... are not money ... Unregulated Crypto Assets can facilitate unlawful behaviour, including drug trade and other illegal activity". ${ }^{31}$ The risks associated with cryptocurrencies such as having a parallel, fragmented, non-sovereign monetary system; consumer protection, market efficiency and integrity issues; undefined regulatory frameworks; and cyber-security make regulation of virtual currencies an imperative.

In designing policy and regulatory frameworks for virtual currencies, regulators face several challenges which are unique and stem from the inherent nature and diverse uses of cryptocurrencies. The major challenges in this regard include the problem of definition and taxonomy, the inherent anonymity of cryptocurrency-transactions, issues of consumer protection and tax regimes and jurisdictional issues, since online transactions can cut across several legal jurisdictions. Cryptocurrencies combine properties of and can function as mediums of exchange, commodities, capital assets, security, and payments systems. The challenge of the taxonomy of cryptocurrencies has legal and regulatory implications. For example, classifying them one way or the other will affect their treatment for the purpose of taxation. ${ }^{32}$ Furthermore, they are designed to allow secured anonymous transactions on decentralised ledgers without an intermediary. A good regulatory framework should contain measures to reduce decentralisation and exert reasonable control over the system. Without robust measures to de-anonymise virtual currency transactions, it will not be easy to identify or trace individual transactions, especially with the prevalence of remote servers. An effective regulatory framework must consider a centralised channel to control transactions and exchanges.

Developing a framework that strikes an appropriate balance between protecting consumers (investors) and enabling legitimate businesses to flourish is another challenge to developing a framework for the regulation of cryptocurrencies. While the protection of consumers against deceit in the highly anonymous cryptocurrency ecosystem is desirable, excessive

"implicit ban" applies in fifteen countries, including Bangladesh, China, Colombia, Indonesia, Iran, Qatar, Saudi Arabia and Taiwan. See Library of Congress 2020 https://www.loc.gov/law/help/cryptocurrency/world-survey.php; Cryptonews 2020 https://cryptonews.com/guides/countries-in-which-bitcoin-is-banned-or-legal.htm. Young $2020 \mathrm{https}: / / w w w . f o r b e s . c o m / s i t e s / y o u n g j o s e p h / 2020 / 06 / 10 / d o n a l d-t r u m p-$ said-bitcoin-is-based-on-thin-air-but-wall-street-is-buying-enmasse/\#407a0a4b4d27. He et al Virtual Currencies and Beyond 24. 
restrictions would inhibit innovation and affect the efficiency of financial markets which could otherwise drive growth and opportunities for investors. ${ }^{33}$ There is a need for a virtual currency regulatory regime to incorporate proper assurance systems to protect investors against fraud and protect their privacy while at the same time enabling legitimate businesses to flourish.

Cryptocurrencies are not restricted within national boundaries but transcend national geographic and legal boundaries in scope, and include a broad range of products and participants; yet there is no uniformity among nations in their regulation. Apart from the traditional conflict of law issues in crossborder transactions, such as which is the applicable law, the forum for the settlement of disputes and the enforcement of foreign judgments, the lack of homogeneity among different jurisdictions' cryptocurrency laws creates difficulties for crypto-exchanges seeking to expand to new markets. Meanwhile, there is no global legal standard on cryptocurrencies. ${ }^{34}$ This underscores the necessity for international co-operation among states in the regulation of cryptocurrencies.

\section{Legal status and regulation of cryptocurrencies in Nigeria}

\subsection{Legal status of cryptocurrencies in Nigeria}

Nigerians "have a high passion for digital currencies and are among the greatest users of cryptocurrencies in the world". ${ }^{35}$ Only recently Nigeria was ranked fifth globally with $11 \%$ of Internet-connected Nigerians owning or using cryptocurrencies. ${ }^{36}$ In 2019 Google Trends, Lagos, Nigeria was the number one city based on online search volumes for Bitcoin worldwide. ${ }^{37}$ Despite the popularity of cryptocurrencies in Nigeria, the initial approach of Nigeria's financial and securities markets regulators, the Central Bank of Nigeria (CBN), and the Securities and Exchange Commission (SEC) towards virtual currencies was that of scepticism and tacit rejection. This resulted in their warnings to banks, financial institutions and capital market operators against dealing in cryptocurrencies. Over time, however, the attitude of the SEC has changed and it is now tilting towards the formal

\footnotetext{
33 Jia and Zhang "Between Liberalization and Prohibition" 99-100.

34 Armstrong, Hyde and Thomas 2019 Blockchain and Cryptocurrency 5.

35 Adesina 2020 https://nairametrics.com/2020/05/24/nigerians-love-for-crypto currencies-on-the-rise-as-it-offers-cheaper-ways-to-transfer-funds.

$36 \quad$ LawCareNigeria $2020 \quad$ https://lawcarenigeria.com/cbn-and-the-question-ofregulating-or-prohibiting-the-nigerian-crypto-market.

37 Sagewriters 2019 https://btc.ng/bitcoin-guide/google-trends-lagos-nigeria-top-cityand-country-searches-for-bitcoin.
} 
recognition and validation of cryptocurrencies. On the other hand, CBN has moved from merely cautioning against dealing in them to prohibiting financial institutions from facilitating transactions in them, a situation which suggests that the two regulatory agencies have adopted diametrically opposing stances in relation to the validity of cryptocurrencies.

There is no legislation in Nigeria that prohibits the use of or dealing in cryptocurrencies. Even the recent directive of the CBN to financial institutions to cease dealing in them has not rendered dealing in cryptocurrencies unlawful. It is mere administrative direction to the regulated institutions, which can attract only administrative sanctions against the institution, although it is intended to make it difficult for persons in Nigeria to deal in cryptocurrencies. Without doubt, nothing stops Nigerians or persons in Nigeria who have foreign bank accounts from dealing in cryptocurrencies using their foreign accounts, and such persons would not be deemed to have committed any offence under Nigerian law. Without an express ban of a conduct, be it an act or omission, such a conduct is deemed to be permitted under the law. This simply means that such a conduct cannot be a crime in the absence of a legal provision declaring it to be so. ${ }^{38}$ Thus, section 36(12) of the Constitution of the Federal Republic of Nigeria, 1999 (as amended) provides that "...a person shall not be convicted of a criminal offence unless that offence is defined and the penalty therefor is prescribed in a written law". The courts have consistently upheld this principle. ${ }^{39}$ It follows that in the absence of a statutory prohibition of cryptocurrencies in Nigeria, their creation, use or dealing in them is lawful, as they do not contravene any law in existence. However, virtual currencies are not legal tender in Nigeria.

A legal tender refers to the money that is legally recognised in a defined jurisdiction as the means of exchange; that is, acceptable for use to purchase goods or services and for the settlement of debt or other obligations. Sono states that legal tender is "money that, if tendered by a debtor in payment of his monetary obligation, may not be refused by the creditor". ${ }^{40}$ Legal tenders take the forms of coins and banknotes created and issued by a statutory authority under national laws or laws of regional formations, such as the EU, with a unique name that identifies it with the particular nation or region and serves as the primary medium of exchange within the jurisdiction.

Stolpe $2010 \mathrm{~J}$ Appl Logic 97-113.

Aoko v Fagbemi (1961) 1 All NLR 1; Amadi v FRN [2011] All FWLR (Pt 561) 1588.

Sono "Legal Tender" 679. 
In Nigeria the body empowered by law to issue legal tender is the CBN. The law also prescribes the unit of currency and its subdivision, which is the Naira, which is divided into one hundred Kobo. ${ }^{41}$ Thus, according to the CBN Act:

The Bank shall have the sole right of issuing currency notes and coins throughout Nigeria and neither the Federal Government nor any State Government or Local Government, other person or authority shall issue currency notes, bank notes or coins or any documents or tokens payable to bearer on demand being document or token which are likely to pass as legal tender. ${ }^{42}$

Currency notes and coins issued by CBN are legal tenders in Nigeria at their face value for the payment of any amount. ${ }^{43}$ The making or counterfeiting of currency and related acts such as being in possession, dealing in, uttering, importing or exporting counterfeit currency are prohibited and punishable under the law. ${ }^{44}$ It is also an offence in Nigeria to engage in acts that depreciate the national currency such as discounting and selling it above the face value, ${ }^{45}$ as well as to import into or export from Nigeria of coin, whether legal tender within Nigeria or not. ${ }^{46}$ These laws largely apply to Nigerian currency and where they apply to foreign currency, they seem to envisage foreign fiat currencies and not virtual currencies. In view of the foregoing, it is therefore submitted that since cryptocurrencies are not issued by CBN or its equivalent in other countries, they are not legal tender and the laws regulating fiat currencies do not apply to them. For cryptocurrency to become generally acceptable in the country there is a need first to integrate it into the monetary system by coupling it with the nation's fiat currency. The use of virtual currency entails the convertibility of fiat money into virtual money and vice versa. However, it appears from the recent stance of Nigeria's central bank and apex financial regulator that the country has adopted a restrictive approach to payment services, which does not recognise payment by means of cryptocurrency. This is a fundamental obstacle that necessitates the amendment of existing monetary regulations if cryptocurrency is to be effectively used in the country. Section 215 of the Central Bank of Nigeria Act 7 of 2007 (the CBN Act); s 1 of the Decimal Currency Act Cap D2 LFN 2004.

Section 17 of the CBN Act.

Sections 16-20 of the CBN Act.

Sections 146-160B of the Criminal Code Act Cap C38 LFN 2004; s 12 of the Counterfeit Currency (Special Provisions) Act Cap C35 LFN 2004.

$45 \quad$ Sections 3 and 4 of the Currency Offences Act Cap C44 LFN 2004. 


\subsection{Regulation of cryptocurrencies in Nigeria}

Some provisions in two Nigerian statutes, namely the Foreign Exchange (Monitoring and Miscellaneous Provisions) Act (the Forex Act) ${ }^{47}$ and the Investment and Securities Act (ISA) ${ }^{48}$ are close to covering and arguably can be extended to cover virtual currencies. The Forex Act establishes an autonomous foreign exchange market and makes provisions for the monitoring and supervision of transactions conducted in the market. Section 2 of the Act provides that transactions in the market shall be conducted in any convertible foreign currency and through the usual money market instruments including foreign bank notes and coins, travellers' cheques, bank drafts, mail and telegraphic transfers and any other such money market instruments as CBN may from time to time determine with the approval of the Minister. Abdul ${ }^{49}$ asserts that even though the Forex Act defines foreign currency as "any currency, other than Nigerian currency", what the Act envisages are foreign fiat currencies. While the assertion is correct in relation to the meaning of currency under the Act, it appears that the author did not advert to the expression "any other money market instruments" in section 2(2)(f) of the Act. However, until a determination of CBN is made with the approval of the Minister of Finance, cryptocurrencies remain outside the scope of the Act. Even though the Act does not specify how CBN's determination in that regard is to be made, presumably what is required is a regulation under section 40 of the Forex Act. Thus, although people in Nigeria can deal in virtual currencies, such transactions cannot be conducted through the official foreign exchange system in the country.

Section 13 of ISA confers powers on the SEC as the apex regulator of the Nigerian capital market to regulate investments and securities market in Nigeria. Section 315 of ISA defines security as debentures, stocks or bonds issued or proposed to be issued by a government or a corporate body; any right or option in respect of such instruments or commodities futures, contracts, options and other derivatives. The term securities includes categories of the instrument which may be transferred by means of electronic mode approved by the SEC and may be deposited, kept or stored with any licensed depository or custodian company approved under the Act. This provision can be extended to cryptocurrencies, but that can be done only with the approval of the Commission whose responsibility it is also to license virtual currency exchanges as depositories or custodians.

\footnotetext{
47 Section 2 of the Foreign Exchange (Monitoring and Miscellaneous Provisions) Act Cap F34 LFN 2004 (the Forex Act).

48 Sections 13 and 315 of the Investment and Securities Act 29 of 2007 (the ISA).

49 Abdul 2018 https://papers.ssrn.com/sol3/papers.cfm?abstract_id=3106296 6 .
} 
Upon the advent of cryptocurrencies in Nigeria, the attitude of the relevant regulatory authorities, the CBN and the SEC, that could exercise the mandates inherent in the Forex Act and ISA respectively to extend the provisions of those statues to cryptocurrencies, was that of cynicism. The suspicion around virtual currencies was heightened by the association of Bitcoin with Ponzi schemes..$^{50}$ In January 2017 the SEC issued a public notice warning Nigerians against investing in cryptocurrencies. In the notice the SEC made it clear that:

...none of the persons, companies or entities promoting cryptocurrencies has been recognised or authorised by it or by other regulatory agencies in Nigeria to receive deposits from the public or to provide any investment or other financial services in or from Nigeria. ${ }^{51}$

The SEC warned that any investment opportunities promoted by such persons, companies or entities were likely to be of a risky nature with a high risk of the loss of money, whilst others may be outright fraudulent pyramid schemes. It also warned that since such instruments and their promoters had not been authorised and no guidelines or regulations had been developed for them by the regulatory authorities in Nigeria, no protection was available to users or investors in virtual currencies from financial losses if the companies promoting them went out of business. ${ }^{52}$

On a similar note, the CBN issued a circular to all banks and other financial institutions in the country drawing attention to the emergence of virtual currencies and warned, among other things, that transactions in them are largely anonymous and untraceable, making them susceptible to abuse by criminals, and that consumer might lose their money without any legal redress in the event of the exchanger's collapsing or closing business. To protect the integrity of the nation's financial system, pending substantive regulation or decision, the $\mathrm{CBN}$ required banks and other financial institutions, among other things, not use, hold or transact in virtual currencies and to ensure that those of their existing customers that are virtual currency exchangers had effective Anti-Money Laundering/Combating Financing of Terrorism (AML/CFT) controls that enabled them to comply with customer identification, verification and transaction monitoring requirements. ${ }^{53}$ Again, in February 2017 the CBN

\footnotetext{
50 For example, the Mavrodi Mudial Moneybox (MMM), via which many Nigerians lost huge sums of money when it suddenly closed down. See Abdul 2018 https://papers.ssrn.com/sol3/papers.cfm?abstract_id=3106296 7. SEC $2017 \mathrm{http}: / / \mathrm{sec} . g o v . n g /$ public-notice-on-investments-in-cryptocurrencies-andother-virtual-or-digital-currencies. SEC 2017 http://sec.gov.ng/public-notice-on-investments-in-cryptocurrencies-andother-virtual-or-digital-currencies.

532 CBN 2017 https://www.cbn.gov.ng/out/2017/fprd/aml\%20january\%202017\% 20circular\%20to\%20fis\%20on\%20virtual\%20currency.pdf para 3.
} 
issued a press release reiterating that cryptocurrencies are not legal tender and are not licensed or regulated by the CBN, and cautioned that dealers and investors in any kind of cryptocurrency in Nigeria are not protected by law. ${ }^{54}$ On 5 February 2021 the CBN wrote to all deposit money banks (DMBs), non-bank financial institutions (NBFIs) and other financial institutions (OFIs) in the country, reminding them that dealing in cryptocurrencies or facilitating payments for cryptocurrency exchanges is prohibited. It directed all DMBs, NBFls and OFIs to identify persons and entities transacting in or operating crypto currency exchanges in their systems to ensure that such accounts were closed forthwith, and threatened to impose severe regulatory sanctions for any breach of the directive..$^{55}$

On the other hand, the SEC has started to show signs of yielding to the formal recognition of cryptocurrencies. At its Third Quarter Capital Market Committee meeting of 2018, held on 14 November 2018, the SEC established a FinTech Roadmap Committee with its terms of reference being to develop a FinTech roadmap for the Nigerian capital market (NMC); to examine the role and value of FinTech in the nation's financial ecosystem; and to recommend efficient and responsible policy regulatory regimes that would balance innovation and consumer protection, among other things. In its report the committee recommended to the SEC, among other things, that to classify cryptocurrency as securities and commodities but not as currency, and to regulate and develop a framework for virtual financial assets exchanges. It also set out detailed timelines for attaining the recommendations, beginning in the first quarter of 2020. ${ }^{56}$ In August 2019 the SEC set up a joint regulator-industry committee called the Blockchain and Virtual Financial Assets Framework Committee, whose mandate includes developing a framework to support innovation and regulation in the blockchain and virtual financial assets, recommending a suitable model for the taxonomy/classification of cryptocurrencies, and advising the SEC on approaches and guidelines to regulate financial virtual assets in relation to the capital market. ${ }^{57}$

While the report of the Blockchain and Virtual Financial Assets Framework Committee is still being awaited, the SEC has in the purported exercise of

\footnotetext{
54 CBN 2017 https://www.cbn.gov.ng/Out/2018/CCD/Press\%20Release\%20on\%20 Virtual\%20Currencies.pdf 1.

$55 \quad$ CBN 2021 https://www.cbn.gov.ng/Out/2021/CCD/Letter\%20on\%20Crypto.pdf 1.

56 FinTech Roadmap Committee 2019 https://sec.gov.ng/wpcontent/uploads/2020/09/Report-of-the-FinTech-Roadmap-Committee-of-theNigerian-Capital-Market_-October-14-2019.pdf 27-30.

57 Diuto 2019 https://diutocoinnews.com.ng/sec-nigeria-sets-up-a-10-membercommittee-to-draft-a-framework-for-blockchain-and-cryptocurrency/2582; Anusionwu 2020 https://www.blockchainafrica.io/the-fintech-roadmapimplementation-committee-of-sec-nigeria-gets-inaugurated.
} 
its powers under section 13 of ISA and by a statement published on its website on 14 September 2020 said that it "will regulate" investments in cryptocurrencies when the character of the investments qualifies as securities transactions. ${ }^{58}$ According to the statement, any person whose activities involve any aspect of blockchain-related and virtual digital asset services ${ }^{59}$ must be registered by the Commission, and will be subject to the regulatory guidelines. Virtual crypto assets are securities unless proven otherwise and the burden of proof in that regard is on the issuer or sponsor of the said assets. The registration process for virtual assets will involve a two-pronged approach - an initial assessment filing to satisfy the burden of proof, and a filing for registration proper, either made directly by the issuer or sponsor, or where the burden of proof is not satisfied. Similarly, all digital assets token offering, ICOs and other blockchain-based offers of digital assets in Nigeria or by Nigerian issuers or sponsors or foreign issuers targeting Nigerian investors shall be subject to the regulation of the Commission. Existing digital assets offerings prior to the implementation of the Regulatory Guidelines will have three months to either submit the initial assessment filing or documents for registration proper. The Commission may require foreign or non-residential issuers or sponsors to establish a branch office in Nigeria. However, foreign issuers or sponsors will be recognised by the Commission where a reciprocal agreement exists between Nigeria and the country of the foreign issuer or sponsor, or where the country of the foreign issuer or sponsor is a member of the International Organisation of Securities Commissions (IOSCO).

The SEC defines "Crypto Asset" as:

a digital representation of value that can be digitally traded and functions as (1) a medium of exchange; and/or (2) a unit of account; and/or (3) a store of value, but does not have legal tender status in any jurisdiction. A Crypto Asset is - neither issued nor guaranteed by any jurisdiction, and fulfils the above functions only by agreement within the community of users of the Crypto Asset; and Distinguished from Fiat Currency and E-money. ${ }^{60}$

Crypto assets as defined and utility tokens are categorised as commodities if traded on a recognised investment exchange or issued as investments. On the other hand, security tokens are categorised as securities, while derivatives and collective investment funds of crypto assets, security tokens

58

SEC 2020 https://sec.gov.ng/statement-on-digital-assets-and-their-classificationand-treatment.

59

60

Such services include but are not limited to the reception, transmission and execution of orders on behalf of other persons, dealers on own account, portfolio management, investment advice, custodian or nominee services.

SEC 2020 https://sec.gov.ng/statement-on-digital-assets-and-their-classificationand-treatment. 
and utility tokens would be regulated as specified investments under the ISA and applicable SEC rules and regulations. ${ }^{61}$

Evidently, the SEC's statement of 14 September 2020 cannot be said to provide a substantive regulation, but it is a pointer to what will come in future. The position remains that there is no substantive regulatory framework for cryptocurrencies in Nigeria, although the initial precautionary stance of the SEC has waned. Even then, keeping within its regulatory function, the SEC focusses on trying to validate cryptocurrencies as assets, the convertibility of which into national currency and the use of which in the official foreign exchange market would remain serious problems to their effectiveness as units of accounts and store of value without a corresponding recognition by the CBN.

\section{Legal status and regulation of cryptocurrencies in South Africa}

\subsection{Legal status of cryptocurrencies in South Africa}

As in Nigeria, cryptocurrencies are popular in the Republic of South Africa (RSA) and are legal in that they are massively used, but they are not legal tender. According to Kemp, ${ }^{62}$ the RSA ranks third globally in the percentage of Internet users who own cryptocurrency, with 13\% per cent of South African Internet users owning some form of cryptocurrency. This compares with the worldwide average of $7 \%$ of Internet users holding cryptocurrencies. As at April 2020, there are approximately 12 crypto trading platforms in the RSA with a market capitalisation value of about R6.5 billion. ${ }^{63}$

The South African Reserve Bank (SARB), established under the SARB Act, is the only authority responsible for currency management in South Africa. The SARB has the sole right to issue or cause to be issued banknotes and coins in the country, ${ }^{64}$ which can be legally offered in payment of a debt or other monetary obligation and which a creditor is obliged to accept. The $S A R B$ Act prescribes the unit of currency and its subdivision, which is the Rand, that is divided into one hundred cents. ${ }^{65} A$ tender of a note of the bank or of an outstanding note of another bank for which the bank has

61 SEC 2020 https://sec.gov.ng/statement-on-digital-assets-and-their-classificationand-treatment.

$62 \quad$ Kemp Digital 2020224.

63 IFWG, CAR WG $2020 \mathrm{https}: / /$ www.ifwg.co.za/wp-content/uploads/IFWG_CAR_WGPosition_Paper_on_Crypto_Assets.pdf 5-6.

64 Section 14 of the South African Reserve Bank Act 90 of 1989 (the SARB Act).

65 Section 15 of the SARB Act. 
assumed liability of payment by money shall be a legal tender of payment of an amount equal to the amount specified on the note. ${ }^{66} \mathrm{It}$ is an offence to counterfeit currency or to engage in related acts such as being in possession, dealing in, uttering, importing or exporting counterfeit currency. ${ }^{67}$

According to the SARB, virtual currencies in their various classifications are not legal tender in South Africa and are not to be "used as payment for the discharge of any obligation in a manner that suggests they are perfect substitutes of legal tender". 68 This means that their acceptance is not binding and a creditor may refuse them as means of payment.

\subsection{Regulation of cryptocurrencies in South Africa}

The initial attitude of the relevant regulatory authorities in the RSA to the emergence of cryptocurrencies was the same as that of their Nigerian counterparts: scepticism and caution. On 18 September 2014 the National Treasury (NT), the SARB, the Financial Services Board (FSB), the South African Revenue Service (SARS) and the Financial Intelligence Centre (FIC) jointly issued a statement warning the public about the risks of dealing or investing in virtual currencies. ${ }^{69}$ The caution was premised on the absence of a legal and regulatory framework and the lack of consumer protection laws. It specifically drew attention to the risks and challenges of virtual currencies, which include that their platforms are prone to operational risks and that they are susceptible to misuse. ${ }^{70}$ In December 2014 the SARB further highlighted the risks associated with the use of virtual currencies, including issues relating to payment systems and payment service providers, price stability, money-laundering and the financing of terrorism, consumer risk, the circumvention of exchange control regulations, and financial instability. ${ }^{71}$

With the increasing popularity and use of cryptocurrency, the South African authorities have recognised the need for and are now working towards the regulation of virtual currencies. In 2016 the Intergovernmental Fintech Working Group (IFWG) was established to study the increasing role of

68

69

70

71

Section 17 of the SARB Act. Also see s 5 of the Currency and Exchange Act 9 of 1933, which amended s 18 of the Currency and Banking Act 31 of 1920, as amended by s 9 of the Currency and Banking Act Amendment Act 22 of 1923.

Section 31(1) of the SARB Act; s 2 of the Prevention of Counterfeiting of Currency Act 16 of 1965.

SARB Position Paper on Virtual Currencies 5.

National Treasury 2014 https://perma.cc/B3D8-NPYS 1.

National Treasury 2014 https://perma.cc/B3D8-NPYS 3.

SARB Position Paper on Virtual Currencies 10. 
financial technology and innovation and explore how regulators can be more proactive in assessing emerging risks and opportunities in South Africa's financial market. The IFWG comprises several collaborating South African financial sector regulators, including the SARB, the SARS, the NT, the FIC, the Financial Sector Conduct Authority (FSCA), and the National Credit Regulator (NCR). ${ }^{72}$ Early in 2018, under the auspices of the IFWG, the Crypto Assets Regulatory Working Group (CAR WG) was formed with the objective of formulating a coherent and comprehensive national policy on crypto assets which would ensure the continued integrity, stability and efficient working of South African financial markets and the protection of the rights and interest of customers and investors, and which would also combat illegitimate cross-border financial flows, money laundering (ML) and terrorism financing (TF). In April 2020 the IFWG and the CAR WG issued a position paper on the establishment of a regulatory framework for crypto assets in the RSA. ${ }^{73}$ The paper emphasises the need to develop policy and regulatory responses to crypto assets in the RSA as the FinTech innovation may impact on the country's financial sector as interest, investment and dealing in them continues to grow. It further noted that crypto assets currently operate in a regulatory void, as there is no harmonised global approach to this FinTech, which has the potential to create "conditions for regulatory arbitrage while posing risks". ${ }^{74}$ The position paper focusses only on non-government/non-central bank issued crypto assets and does not address central bank issued digital currencies. It concentrates mainly on five uses of crypto assets, namely buying and/or selling by consumers and other legal persons; using them for payments; ICOs; funds and derivatives; and market support services. ${ }^{75}$ Recognising that crypto assets can perform functions similar to those of fiat currencies, securities, financial products and commodities, the South African regulatory authorities have adopted a functional approach in defining the term as:

... a digital representation of value that is not issued by a central bank, but is traded, transferred and stored electronically by natural and legal persons for

\footnotetext{
72 IFWG 2020 https://www.resbank.co.za/content/dam/sarb/publications/mediareleases/2020/9847/IFWG-Frequently-asked-questions.pdf 1.

73 IFWG and CAR WG 2020 https://www.ifwg.co.za/wpcontent/uploads/IFWG_CAR_WG-Position_Paper_on_Crypto_Assets.pdf 6 .

74 IFWG and $\mathrm{CAR}$ WG 2020 https://www.ifwg.co.za/wpcontent/uploads/IFWG_CAR_WG-Position_Paper_on_Crypto_Assets.pdf 4-5.

75 IFWG and CAR WG 2020 https://www.ifwg.co.za/wpcontent/uploads/IFWG_CAR_WG-Position_Paper_on_Crypto_Assets.pdf 6-7.
} 
the purpose of payment, investment and other forms of utility, and applies cryptography techniques in the underlying technology. ${ }^{76}$

The paper highlights both the generic risks of crypto assets as well as specific risks posed by them in their uses, and identifies the challenges of regulating them. It outlines the objectives and principles of regulating crypto assets, and based on the existing landscape and levels of adoption, acceptance and use of crypto assets in the RSA, puts forward a number of overall policy positions and recommendations ${ }^{77}$ as well as policy positions and recommendations on each of the five identified uses of crypto assets. ${ }^{78}$ In all, the paper contains thirty recommendations that are in compliance with the standards set by the Financial Action Task Force, the global money laundering and terrorist financing watchdog. ${ }^{79}$ Some of the recommendations include that entities providing crypto asset services be regarded as Crypto Assets Service Providers; ${ }^{80}$ and crypto assets remain without legal tender or electronic money status and should not be permitted for the conduct of money settlements in financial market infrastructure such as the South African Multiple Option Settlement (SAMOS) system, which is the real-time gross settlement system in the country. ${ }^{81}$

Even though there is yet no regulation on virtual currencies in the RSA, there are restrictions on cross-border or foreign exchange transfers for the purposes of buying crypto assets, as well as on the repatriation of funds by non-residents who sell virtual currencies in the RSA. Currently, from the exchange control point of view, the Financial Surveillance Department of the SARB does not approve transactions for cross-border exchange transfers for the explicit purpose of buying virtual currencies, as such transactions are not allowed under either the Currency and Exchanges Manual for Authorised Dealers or the Currency and Exchanges Manual for Authorised Dealers on foreign currency with limited authority. ${ }^{82}$ However, currently the purchase of virtual currencies from abroad can be done by the use of an individual's single discretionary allowance (R1 million) and/or

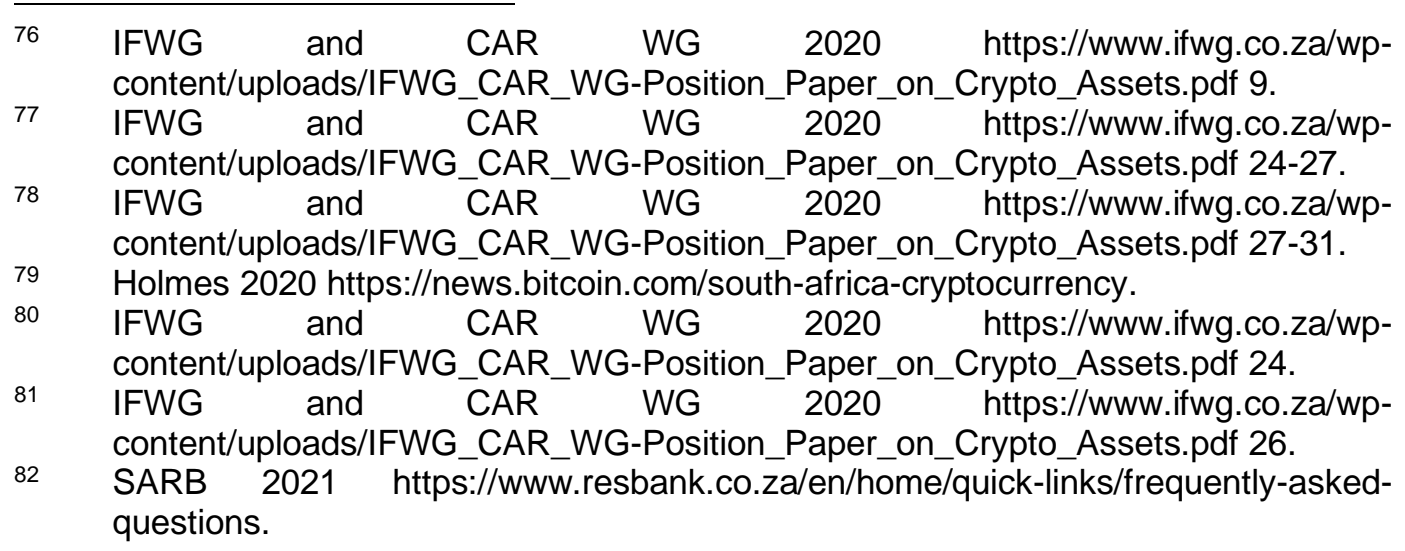


individual foreign capital allowance (R10 million with a Tax Clearance Certificate), per calendar year. ${ }^{83}$ Furthermore, according to SARB, nonresidents who introduce virtual currencies into the RSA for sale locally and who want to transfer the proceeds of such a sale abroad cannot do so under the exchange control policy. ${ }^{84}$

In terms of taxation, crypto assets are regulated in terms of the Income Tax $A c t^{85}$ and the Value-Added Tax Act (the VAT Act). Normal tax rules apply to cryptocurrencies and taxpayers are expected to make declarations of their gains from cryptocurrency as part of their taxable income. Failure to do so could result in the imposition of interest and penalties. ${ }^{86}$ However, under the VAT Act "the issue, acquisition, collection, buying or selling or transfer of ownership of any crypto currency" is exempt from financial services, ${ }^{87}$ but any fee related to that service will be subject to VAT at $15 \%$, if the supplier of the service/the fee earner exceeds the registration threshold. ${ }^{88}$

\section{A comparison of the state of regulation of cryptocurrencies in Nigeria and South Africa}

There is no consensus among nations and regulatory authorities in some countries on the name and classification of cryptocurrencies. Thus, various names and classifications are applied in attempts to identify, describe or delineate the crypto phenomenon, but no particular name or classification appears to be particularly apposite or suitable to encompass the nature and various uses of virtual currencies. The nomenclature and definitions that have been applied refer mostly to the decentralised technology that drives the phenomenon (blockchain and distributed ledger technology) or its digital nature, as well as to its actual, perceived and potential roles as a medium of exchange and as a representation of value. Thus, while some jurisdictions have classified it as a unit of account, others have rejected it as a financial instrument or financial product. Central banks, as fiat currency regulators, have not been supportive of the idea of referring to the phenomenon as "currency" as it is not legal tender. To avoid the use of the

\footnotetext{
83 SARB 2021 https://www.resbank.co.za/en/home/quick-links/frequently-askedquestions.

SARB 2021 https://www.resbank.co.za/en/home/quick-links/frequently-askedquestions.

See s 7(1) of the Income Tax Act 58 of 1962, which provides for when income is deemed to have accrued or been received for the purposes of taxation under the Act. SARS-stance-on-the-tax-treatment-of-cryptocurrencies-.aspx.

87 Section 12 of the Value-Added Tax Act 89 of 1991 (the VAT Act).

88 IFWG and CAR WG 2020 https://www.ifwg.co.za/wp-content/uploads/IFWG CAR_WG-Position_Paper_on_Crypto_Assets.pdf 27.
} 
term currency in the name, Nigeria appears to have toed the line of the RSA in the taxonomy and classification of the phenomenon as "assets", in proposing to adopt the name "crypto assets". Evidently, this does capture all the essentials of the phenomenon as it tends to downplay those of its functions which are similar to those of fiat currencies, securities, financial products and commodities.

Furthermore, while the IFWG-CAR WG position paper comprehensively articulates South Africa's policy position and could ultimately serve as a framework for legislation on the subject, the statement of Nigeria's SEC on digital assets, their classification and treatment ${ }^{89}$ is the direct opposite. The SEC's statement is the product of one regulatory authority and, as far as the subject matter is concerned, quite incomprehensive. There appears to be a lack for synergy amongst the regulatory authorities in Nigeria on the matter. There is no evidence that Nigeria's financial regulator the CBN, her security regulator the SEC, or any other necessary relevant authorities such as the insurance regulator or the commodities exchange are collaborating to produce Nigeria's policy position on cryptocurrencies, as is obtainable in other countries. ${ }^{90}$ Both the FinTech Roadmap Committee and the resultant Blockchain and Virtual Financial Assets Framework Committee were set up by the SEC. Such a fragmented approach to the regulation of cryptocurrency would not give the desired result, to say the least. It is disturbing that the SEC rushed to release the statement of 14 September 2020, thus pre-empting the Blockchain and Virtual Financial Assets Framework Committee it set up. The fact that there is no indication that the statement was based on a preliminary report by that committee creates the impression of the existence of a strained relationship between the SEC and the Committee.

Unlike the position in the RSA, there is a total absence of provisions on the treatment of cryptocurrency under Nigerian tax laws. Given the volume of cryptocurrency transactions in Nigeria, there is a need to distinguish

SEC 2020 https://sec.gov.ng/statement-on-digital-assets-and-their-classificationand-treatment.

90 Apart from the position in the RSA, in China seven central government regulators, the People's Bank of China (PBOC), the Cyberspace Administration of China (CAC), the Ministry of Industry and Information Technology (MIIT), the State Administration for Industry and Commerce (SAIC), the China Banking Regulatory Commission (CBRC), the China Securities Regulatory Commission (CSRC), and the China Insurance Regulatory Commission (CIRC), work jointly to enforce the restriction of virtual currencies. See Pilarowski and Yue 2017 http://www.pillarlegalpc.com/ en/legalupdates/wp-content/uploads/2020/08/PL-China-Regulation-WatchCryptocurrency-2017-09-22.pdf 3; Xu 2018 http://www.scmp.com/business/ banking-finance/article/2132009/china-stamp-out-cryptocurrency-tradingcompletely-ban. 
between the regulation and taxation of virtual currency transactions. ${ }^{91}$ Thus, while the comprehensive regulation of cryptocurrencies is being awaited, transactions in them should be liable to taxes, depending on the nature of the transactions. For example, income realised from trading in cryptocurrency should ordinarily constitute chargeable income for income tax purpose under the Personal Income Tax Act ${ }^{92}$ in the case of individuals and under the Companies Income Tax $\mathrm{Act}^{93}$ for companies. Where such transactions are of a capital nature, cryptocurrencies may well constitute chargeable assets for capital gains tax under the Capital Gains Tax Act. ${ }^{94}$ Although ordinarily cryptocurrency transactions may not be classified as the "supply of goods and services" under section 2 of the Nigerian Value Added Tax Act, ${ }^{95}$ the use of cryptocurrency as payment for the supply of VATable goods or services brings such a transaction within the ambit VAT. ${ }^{96}$ This appears to be the position with the VAT treatment of such transactions in the UK, although the UK tax authorities charge VAT on the Pound Sterling value of the cryptocurrency paid for goods or services as opposed to the market value of such goods or services. ${ }^{97}$

Furthermore, South Africa has placed restrictions on foreign exchange transfers for the purposes of buying crypto assets as well as the repatriation of income from trading in crypto assets by non-residents. On the other hand, in Nigeria, with the recent directive by the CBN to commercial banks and other financial institutions in the country to close the accounts of persons and entities transacting in or operating crypto currency exchanges in their systems, foreign exchange transfers relating to crypto assets and the repatriation of income from trading in them into or out of the country will no longer be possible. The directive does not make any distinction between Nigerian residents and non-residents. This clearly puts an end to any foreign exchange transactions in cryptocurrencies through any financial institution in Nigeria. While analysts have expressed fears of capital flight from the country, the Nigerian government, which has been waging war against insurgency and terrorism for nearly two decades, has justified the action in

\footnotetext{
$91 \quad$ Ezomike and Isiadinso 2018 Anderson Tax Newsletter 3.

92 Section 3 of the Personal Income Tax Act Cap P8 LFN 2004 (as amended).

93 Section 9 of the Companies Income Tax Act Cap C21 LFN 2004.

94 See ss 3 and 6 of the Capital Gains Act Cap C1 LFN 2004 (as amended).

95 See ss 2 and 3 of the Value Added Tax Act Cap V1 LFN 2004. Note that financial services are not exempt from chargeable goods and services under the Act.

96 Under ss $5(1)(b)(2)$ and (3) of the VAT Act, where the supply of VATable goods or services is for a consideration other than money, the market value of such a supply shall be deemed to be the value for VAT purposes. 
terms of the tendency of cryptocurrencies to be used for money laundering and the financing of terrorism. ${ }^{98}$

\section{Regulation of cryptocurrencies in the US and the EU}

As in Nigeria and RSA, cryptocurrency is not considered as legal tender in the US, but dealing in it is legal. At the federal level the US authorities differ in their categorisation of cryptocurrencies. While the Financial Crimes Enforcement Network (FinCEN) since 2013 considers them to be mediums of exchange on the basis that tokens are "other value that substitutes for currency" under the Code of Federal Regulations (CFR), ${ }^{99}$ the Inland Revenue Services (IRS) by contrast regard cryptocurrencies as property, and have issued tax guidance accordingly. ${ }^{100}$ The US Securities and Exchange Commission (USSEC) considers cryptocurrencies to be securities, while the Commodities Futures Trading Commission (CFTC) describes Bitcoin and cryptocurrency derivatives as commodities and allows them to be traded publicly. The Justice Department is collaborating with the USSEC and the CFTC to streamline regulatory oversight and ensure effective consumer protection. Presently a bill ${ }^{101}$ for comprehensive legislation on cryptocurrency is pending before the US Congress. ${ }^{102}$. The stated objectives of the proposed law, which seeks to comprehensively regulate cryptocurrencies in the US, is to clarify which Federal agencies regulate digital assets, to require those agencies to notify the public of any federal licences, certifications, or registrations required to create or trade in such assets, and for other purposes.

Novel provisions of the Bill include the clear differentiation of classes/categories of cryptocurrencies based on their key functions and assigning the regulation of each to a different regulator. Section 2 of the Bill groups cryptocurrencies into three classes/categories, namely: cryptocommodities, crypto-currencies and crypto-securities. The section also defines each and assigns primary regulatory oversight over them to the FTC, the Secretary of the Treasury acting through the FinCEN and the Comptroller of Currency, and the USSEC respectively. ${ }^{103}$ Each regulator

Proshare 2019 https://www.proshareng.com/news/\%20BLOCKCHAIN\%20\&\%20CRYPTOS/ Cryptocurrency-Ban-and-its-Economic-Implications/56279.

Regulation 1010.100(ff)(5)(i)(A) of the Code of Federal Regulations 31 CFR $\S$ 1010.100 (the CFR). See FinCEN 2013 https://www.fincen.gov/resources/statutesregulations/guidance/application-fincens-regulations-persons-administering;

FinCEN 2019 https://www.fincen.gov/sites/default/files/2019-05/FinCEN\%20 Guidance\%20CVC\%20FINAL\%20508.pdf 4.

100 IRS 2014 https://www.irs.gov/newsroom/irs-virtual-currency-guidance.

101 The bill for the Crypto-Currency Act of 2020 was presented to the US House of Representatives on 9 March 2020. See $116^{\text {th }}$ Congress, 2D Session HR 6154.

102 Helms 2020 https://news.bitcoin.com/cryptocurrency-act-of-2020.

103 Section 3 of the Crypto-Currency Bill 2020. 
shall maintain a list of all exchanges trading in the digital asset assigned to it. ${ }^{104}$ Each primary Federal digital asset regulator shall, with respect to digital assets over which it is the primary Federal digital asset regulator, make available to the public (and keep current) a list of all Federal licences, certifications or registrations required to create or trade in digital assets. ${ }^{105}$ However, for the purposes of tracing transactions in cryptocurrencies the Secretary of the Treasury, acting through the FinCEN, shall issue rules to require each cryptocurrency to allow for the tracing of transactions in the cryptocurrency and persons engaging in such transactions in a manner similar to that required of financial institutions with respect to currency transactions. ${ }^{106}$

Four agencies are involved in the regulation of cryptocurrencies in the EU - the European Commission (the Commission), the European Banking Authority (EBA), the European Insurance and Occupational Pensions Authority (EIOPA) and the European Securities and Markets Authority (ESMA). The Commission is responsible for planning and proposing legislation; monitoring the effectiveness of financial sector reforms; and responding to emerging financial stability risks. The functions of the EBA include carrying out "regular horizon-scans in relation to innovative products and services", including those related to crypto assets, "from the perspectives of monitoring the impact on the financial system, [and] the suitability of the regulatory perimeter under EU law". The EIOPA monitors the developments of cryptocurrencies and ICOs in the insurance sector while the ESMA is responsible for safeguarding the stability of the EU's financial system.

The applicable regulation includes the Directive on the Prevention of the Use of Financial Systems for the Purposes of Money Laundering or Terrorist Financing ${ }^{107}$ which came into force on 10 January 2020, being the date that the EU member States were obligated to bring into force the laws, regulations and administrative provisions necessary to comply with the Directive. In terms of the Directive, currency exchange platforms are to fulfil due diligence requirements and have in place policies and procedures to

\footnotetext{
104 Section 4 of the Crypto-Currency Bill 2020.

105 Section 5 of the Crypto-Currency Bill 2020.

106 Section 6 of the Crypto-Currency Bill 2020.

107 Directive on the Prevention of the Use of Financial System for the Purposes of Money Laundering or Terrorist Financing 2018/843/EC amending Directive on the Prevention of the Use of the Financial System for the Purposes of Money Laundering or Terrorist Financing 2015/849/EU and amending Directive on the Taking-Up and Pursuit of the Business of Insurance and Reinsurance (Solvency II) 2009/138/EC and Directive on Access to the Activity of Credit Institutions and the Prudential Supervision of Credit Institutions and Investment Firms 2013/36/EU.
} 
detect, prevent, and report money laundering and terrorist financing. It defines virtual currency as:

a digital representation of value that is neither issued by a central bank or a public authority, nor necessarily attached to a fiat currency, but is accepted by natural or legal persons as a means of payment and can be transferred, stored or traded electronically. ${ }^{108}$

The European Court of Justice (ECJ) on 22 October 2015 in the case of Skatteverket $v$ David Hedqvist ${ }^{109}$ held that transactions to exchange a traditional currency for bitcoin and vice versa constitute the supply of services for consideration. It can be argued that although the case relates only to Bitcoin, the decision will apply to other cryptocurrencies. The court also held in the case that such transactions are exempt from value added tax (VAT) under Article 135 of the Directive on the Common System of Value Added Tax. ${ }^{110}$ However, while it appears that the Directive as well as case law recognises virtual currencies as a medium of exchange it is doubtful whether it can be considered legal tender, as the Directive clearly states that "it is not necessarily attached to a fiat currency". As such, a person cannot legally be compelled to receive it in a transaction unless he is bound by any agreement to that effect.

In fact, in February 2018 the ESMA, the EBA and the EIOPA issued a joint statement to warn consumers regarding virtual currencies, stating that they are "highly risky and unregulated products and are unsuitable as investment, savings or retirement planning products". ${ }^{111}$

\section{Concluding remarks}

Given the nature and pervasiveness of cryptocurrencies, it has become imperative to regulate the technology. It appears that the enigmatic FinTech innovation caught financial regulators unawares, and like an unruly horse, every nation is grappling with how to rein it in. Presently it is doubtful if any jurisdiction has achieved perfect regulation of the ambivalent cryptocurrency market which can be emulated by others.

\footnotetext{
108 Article 1(d) of the Directive on the Prevention of the Use of Financial System for the Purposes of Money Laundering or Terrorist Financing 2018/843/EC.

109 Skatteverket $v$ David Hedqvist Case C-264/14 of 22 October 2015.

110 Directive on the Common System of Value Added Tax 2006/112/EC.

111 EIOPA $2018 \mathrm{https}$ ://www.eiopa.europa.eu/content/esas-warn-consumers-risksbuying-virtual-currencies-0_en.
} 
Irrespective of the name and classification adopted for cryptocurrency, in designing policy and regulatory frameworks for it, it is suggested that the following should be incorporated:

(a) the registration and control of entities trading in cryptocurrencies (licensure);

(b) a minimum capital requirement for the entities and appropriate mandatory insurance cover for the entities;

(c) appropriate technology to record and track transactions;

(d) an effective tax regime for cryptocurrency; and

(e) appropriate dispute resolution and redress mechanisms for consumers.

There is a need for the amendment of relevant existing laws on financial services, securities and commodities (futures) and the involvement of multisectoral agencies in order to pool the resources necessary to address the octopus-like nature and reach of cryptocurrency. In Nigeria, synergy among relevant agencies such as the CBN, the SEC, the Nigerian Deposit Insurance Corporation (NIDC), the Economic and Financial Crimes Commission (EFCC), the National Information Technology Development Agency (NITDA) and the Federal Competition and Consumer Protection Commission should be encouraged in the design and implementation of policy and regulatory frameworks for cryptocurrency.

Having an effective regulation of the crypto market would obviate the negative criminal propensities of the technology and foster consumer confidence not only in crypto assets but also in the national financial systems and the economic environment. Regulation would also provide a steady source of revenue for government through the imposition of taxes. Furthermore, in view of the borderless nature of virtual currencies, relevant national regulatory authorities should establish linkages and cooperation with similar agencies in other countries on information sharing; particularly on the tracking of cross-border transactions. It is possible to develop and implement policies and regulations for cryptocurrencies, and there is no better time to do so than now. 


\section{Bibliography}

\section{Literature}

Antonopoulos Mastering Bitcoin

Antonopoulos AM Mastering Bitcoin - Unlocking Digital Crypto-Currencies (O'Reilly Sebastopol CA 2014)

Armstrong, Hyde and Thomas Blockchain and Cryptocurrency

Armstrong D, Hyde D and Thomas S Blockchain and Cryptocurrency: International Legal and Regulatory Challenges (Bloomsbury London 2019)

Clements 2018 MBELR

Clements R "Assessing the Evolution of Cryptocurrency: Demand Factors, Latent Value, and Regulatory Developments" 2018 MBELR 73-100

Dorfleitner et al "Definition of FinTech"

Dorfleitner $\mathrm{G}$ et al "Definition of FinTech and Description of the FinTech Industry" in Dorfleitner G et al (eds) FinTech in Germany (Springer Cham 2017) $5-10$

Ezomike and Isiadinso 2018 Anderson Tax Newsletter

Ezomike $\mathrm{C}$ and Isiadinso $\mathrm{O}$ "Cryptocurrency and Taxes: Bridging the Digital Gap" July 2018 Anderson Tax Newsletter 1-4

Franco Understanding Bitcoin

Franco P Understanding Bitcoin - Cryptography, Engineering, and Economics (Wiley Chichester 2015)

Galavis 2019 U Miami Int'l \& Comp L Rev

Galavis $\mathrm{J}$ "Blame it on the Blockchain: Cryptocurrencies Boom amidst Global Regulations" 2019 U Miami Int'I \& Comp L Rev 561-596

Gobble 2018 RTM

Gobble MM "Digitalization, Digitization, and Innovation" 2018 RTM 56-59

He et al Virtual Currencies and Beyond

He D et al Virtual Currencies and Beyond: Initial Considerations - IMF Staff Discussion Note (IMF New York 2016)

Jia and Zhang "Between Liberalization and Prohibition" Jia $\mathrm{K}$ and Zhang $\mathrm{F}$ "Between Liberalization and Prohibition: Prudent Enthusiasm and the Governance of Bitcoin/Blockchain Technology" in Campbell-Verduyn M (ed) Bitcoin and Beyond - Cryptocurrencies, Blockchains, and Global Governance (Routledge London 2018) 89-108 
Kemp Digital 2020

Kemp S Digital 2020: Global Digital Overview - Essential Insights into How People around the World Use the Internet (We are Social and Hootsuite New York 2020)

Krugman New York Times

Krugman P "Bubble, Bubble, Fraud and Trouble" New York Times (29 January 2018) 23

Lansky 2018 J Syst Integrat

Lansky J "Possible State Approaches to Cryptocurrencies" $2018 \mathrm{~J}$ Syst Integrat 19-31

Mention 2019 RTM

Mention A "The Future of Fintech" 2019 RTM 59-63

Rose 2015 IBER

Rose C "The Evolution of Digital Currencies: Bitcoin, a Cryptocurrency Causing a Monetary Revolution" 2015 IBER 617-622

SARB Position Paper on Virtual Currencies

South African Reserve Bank National Payment System Department Position Paper on Virtual Currencies - Position Paper No 02/2014 (SARB Pretoria 2014)

Schuefell 2016 JIM

Schuefell P "Taming the Beast: A Scientific Definition of Fintech" $2016 \mathrm{JIM}$ $32-54$

Sono "Legal Tender"

Sono K "Legal Tender: A Notion Associated with Payment" in International Monetary Fund Current Developments in Monetary and Financial Law (IMF Washington DC 2003) 679-687

Stolpe $2010 \mathrm{~J}$ Appl Logic

Stolpe A "A Theory of Permission Based on the Notion of Derogation" 2010 J Appl Logic 97-113

World Bank Cryptocurrencies and Blockchains

World Bank Cryptocurrencies and Blockchains - World Bank ECA Economic Update (World Bank Washington DC 2018)

\section{Case law}

Amadi v FRN [2011] All FWLR (Pt 561) 1588 
Aoko v Fagbemi (1961) 1 All NLR 1

Skatteverket v David Hedqvist Case C-264/14 of 22 October 2015

\section{Legislation}

\section{European Union}

Directive on Access to the Activity of Credit Institutions and the Prudential Supervision of Credit Institutions and Investment Firms 2013/36/EU

Directive on the Common System of Value Added Tax 2006/112/EC

Directive on the Prevention of the Use of Financial System for the Purposes of Money Laundering or Terrorist Financing 2018/843/EC

Directive on the Prevention of the Use of the Financial System for the Purposes of Money Laundering or Terrorist Financing 2015/849/EU

Directive on the Taking-Up and Pursuit of the Business of Insurance and Reinsurance (Solvency II) 2009/138/EC

\section{Nigeria}

Capital Gains Tax Act Cap C1 LFN 2004

Central Bank of Nigeria Act 7 of 2007

Coins Act Cap C16 LFN 2004

Companies Income Tax Act Cap C21 LFN 2004

Constitution of the Federal Republic of Nigeria, 1999

Counterfeit Currency (Special Provisions) Act Cap C35 LFN 2004

Criminal Code Act Cap C38 LFN 2004

Currency Offences Act Cap C44 LFN 2004

Decimal Currency Act Cap D2 LFN 2004

Foreign Exchange (Monitoring and Miscellaneous Provisions) Act Cap F34 LFN 2004

Investment and Securities Act 29 of 2007

Personal Income Tax Act Cap P8 LFN 2004 
Value Added Tax Act Cap V1 LFN 2004

South Africa

Currency and Banking Act 31 of 1920

Currency and Banking Act Amendment Act 22 of 1923

Currency and Exchange Act 9 of 1933

Income Tax Act 58 of 1962

Prevention of Counterfeiting of Currency Act 16 of 1965

South African Reserve Bank Act 90 of 1989

Value-Added Tax Act 89 of 1991

\section{United States of America}

Code of Federal Regulations 31 CFR $\S 1010.100$

Crypto-Currency Act (Bill) 2020, 116 ${ }^{\text {th }}$ Congress, 2D Session HR 6154

\section{Internet sources}

Abdul 2018 https://papers.ssrn.com/sol3/papers.cfm?abstract_id=3106296 Abdul AO 2018 Cryptocurrencies in Nigeria: A Legal Analysis https://papers.ssrn.com/sol3/papers.cfm?abstract_id=3106296 accessed 12 September 2020

Adesina 2020 https://nairametrics.com/2020/05/24/nigerians-love-forcryptocurrencies-on-the-rise-as-it-offers-cheaper-ways-to-transfer-funds Adesina O 2020 Nigerians' Love for Cryptocurrencies on the Rise, as it Offers Cheaper Ways to Transfer Funds https://nairametrics.com/ 2020/05/24/nigerians-love-for-cryptocurrencies-on-the-rise-as-it-offerscheaper-ways-to-transfer-funds accessed 20 October 2020

Anusionwu $2020 \mathrm{https}$ :/www.blockchainafrica.io/the-fintech-roadmapimplementation-committee-of-sec-nigeria-gets-inaugurated

Anusionwu F 2020 The Fintech Roadmap Implementation Committee of SEC Nigeria, gets Inaugurated https://www.blockchainafrica.io/the-fintechroadmap-implementation-committee-of-sec-nigeria-gets-inaugurated accessed 14 October 2020

CBN 2017 https://www.cbn.gov.ng/out/2017/fprd/aml\%20january\% 202017\%20circular\%20to\%20fis\%20on\%20virtual\%20currency.pdf 
Central Bank of Nigeria 2017 Circular to Banks and Other Financial Institutions on Virtual Currency Operations in Nigeria https://www.cbn.gov.ng/out/2017/fprd/aml\%20january\%202017\%20circula r\%20to\%20fis\%20on\%20virtual\%20currency.pdf accessed 15 October 2020

CBN 2017 https://www.cbn.gov.ng/Out/2018/CCD/Press\%20Release\% 20on\%20Virtual\%20Currencies.pdf

Central Bank of Nigeria 2017 Virtual Currencies not Legal Tender in Nigeria https://www.cbn.gov.ng/Out/2018/CCD/Press\%20Release\%20on\%20Virtu al\%20Currencies.pdf accessed 12 October 2020

CBN $2021 \quad$ https://www.cbn.gov.ng/Out/2021/CCD/Letter\%20on\% 20Crypto.pdf

Central Bank of Nigeria 2021 Letter to All Deposit Money Banks, NonFinancial Financial Institutions and Other Financial Institutions https://www.cbn.gov.ng/Out/2021/CCD/Letter\%20on\%20Crypto.pdf accessed 18 February 2021

CoinMarketCap $2020 \mathrm{https}: / /$ coinmarketcap.com/charts

CoinMarketCap 2020 Global Charts: Total Market Capitalisation https://coinmarketcap.com/charts accessed 18 February 2021

Cryptonews 2020 https://cryptonews.com/guides/countries-in-whichbitcoin-is-banned-or-legal.htm

Cryptonews 2020 Countries Where Bitcoin is Banned or Legal in 2020 https://cryptonews.com/guides/countries-in-which-bitcoin-is-banned-orlegal.htm accessed 18 October 2020

Diuto 2019 https://diutocoinnews.com.ng/sec-nigeria-sets-up-a-10member-committee-to-draft-a-framework-for-blockchain-andcryptocurrency/2582

Diuto T 2019 SEC Nigeria Sets Up a 10 Member Committee to Draft a Framework for Blockchain and Cryptocurrency https://diutocoinnews.com.ng/sec-nigeria-sets-up-a-10-membercommittee-to-draft-a-framework-for-blockchain-and-cryptocurrency/2582 accessed 20 October 2020

EIOPA $2018 \mathrm{https://www.eiopa.europa.eu/content/esas-warn-consumers-}$ risks-buying-virtual-currencies-0_en European Insurance and Occupational Pensions Authority 2018 ESAs Warn Consumers of Risks in Buying Virtual Currencies 
https://www.eiopa.europa.eu/content/esas-warn-consumers-risks-buyingvirtual-currencies-0_en accessed 12 September 2020

European Central Bank 2012 https://www.ecb.europa.eu/pub/pdf /other/virtualcurrencyschemes201210en.pdf

European Central Bank 2012 Virtual Currency Schemes https://www.ecb.europa.eu/pub/pdf/other/virtualcurrencyschemes201210e n.pdf accessed 12 September 2020

FinCEN 2013 https://www.fincen.gov/resources/statutes-regulations/ guidance/application-fincens-regulations-persons-administering

Financial Crimes Enforcement Network 2013 Application of FinCEN's Regulations to Persons Administering, Exchanging, or Using Virtual Currencies https://www.fincen.gov/resources/statutes-regulations/ guidance/application-fincens-regulations-persons-administering accessed 19 October 2020

FinCEN $2019 \quad$ https://www.fincen.gov/sites/default/files/201905/FinCEN\%20Guidance\%20CVC\%20FINAL\%20508.pdf

Financial Crimes Enforcement Network 2019 FinCEN Guidance: Application of FinCEN's Regulations to Certain Business Models Involving Convertible Virtual Currencies https://www.fincen.gov/sites/default/ files/2019-05/FinCEN\%20Guidance\%20CVC\%20FINAL\%20508.pdf accessed 20 October 2020

FinTech Roadmap Committee 2019 https://sec.gov.ng/wpcontent/uploads/2020/09/Report-of-the-FinTech-Roadmap-Committee-ofthe-Nigerian-Capital-Market_-October-14-2019.pdf Fintech Roadmap Committee of the Nigerian Capital Market 2019 The Future of Fintech in Nigeria https://sec.gov.ng/wp-content/ uploads/2020/09/Report-of-the-FinTech-Roadmap-Committee-of-theNigerian-Capital-Market_-October-14-2019.pdf accessed 30 September 2020

Greenberg 2011 https://www.forbes.com/forbes/2011/0509/technologypsilocybin-bitcoins-gavin-andresen-crypto-currency.html\#75863f77353e Greenberg A 2011 Crypto Currency https://www.forbes.com/ forbes/2011/0509/technology-psilocybin-bitcoins-gavin-andresen-cryptocurrency.html\#75863f77353e accessed 12 October 2020

Helms 2020 https://news.bitcoin.com/cryptocurrency-act-of-2020 Helms K 2020 US Lawmaker Introduces Crypto-Currency Act of 2020 while Under Coronavirus Quarantine https://news.bitcoin.com/cryptocurrencyact-of-2020 accessed 12 October 2020 
Henry and Irrera 2017 https://www.reuters.com/article/us-usa-banksconference-jpmorgan/jpmorgans-dimon-says-bitcoin-is-a-fraudidUSKCN1BN2KP

Henry D and Irrera A 2017 JP Morgan's Dimon Says Bitcoin "is a Fraud" https://www.reuters.com/article/us-usa-banks-conference-

jpmorgan/jpmorgans-dimon-says-bitcoin-is-a-fraud-idUSKCN1BN2KP accessed 15 October 2020

Holmes 2020 https://news.bitcoin.com/south-africa-cryptocurrency Holmes K 2020 South Africa Proposes 30 Rules to Regulate Cryptocurrency https://news.bitcoin.com/south-africa-cryptocurrency accessed 20 October 2020

IFWG 2020 https://www.resbank.co.za/content/dam/sarb/publications/ media-releases/2020/9847/IFWG-Frequently-asked-questions.pdf Intergovernmental Fintech Working Group 2020 Intergovernmental Fintech Working Group (IFWG) Innovation Hub FAQs https://www.resbank.co.za/content/dam/sarb/publications/mediareleases/2020/9847/IFWG-Frequently-asked-questions.pdf accessed 18 October 2020

IFWG and CAR WG 2020 https://www.ifwg.co.za/wpcontent/uploads/IFWG_CAR_WG-Position_Paper_on_Crypto_Assets.pdf Intergovernmental Fintech Working Group and Crypto Assets Regulatory Working Group 2020 Position Paper on Crypto Assets https://www.ifwg.co.za/wp-content/uploads/IFWG_CAR_WGPosition_Paper_on_Crypto_Assets.pdf accessed 17 October 2020

Imbert 2017 https://www.cnbc.com/2017/09/12/jpmorgan-ceojamie-dimonraises-flag-on-trading-revenue-sees-20-percent-fall-for-the-thirdquarter.html Imbert F 2017 JP Morgan CEO Jamie Dimon Says Bitcoin is a "Fraud" that will Eventually Blow Up https://www.cnbc.com/2017/09/12/jpmorganceojamie-dimon-raises-flag-on-trading-revenue-sees-20-percent-fall-forthe-third-quarter.html accessed 25 October 2020

IRS 2014 https://www.irs.gov/newsroom/irs-virtual-currency-guidance Inland Revenue Services 2014 IRS Virtual Currency Guidance: Virtual Currency is Treated as Property for US Federal Tax Purposes; General Rules for Property Transactions Apply https://www.irs.gov/newsroom/irsvirtual-currency-guidance accessed 20 October 2020 
LawCareNigeria $2020 \mathrm{https}$ ///lawcarenigeria.com/cbn-and-the-question-ofregulating-or-prohibiting-the-nigerian-crypto-market

LawCareNigeria 2020 CBN and the Question of Regulating or Prohibiting the Nigerian Crypto Market https:/lawcarenigeria.com/cbn-and-thequestion-of-regulating-or-prohibiting-the-nigerian-crypto-market accessed 23 October 2020

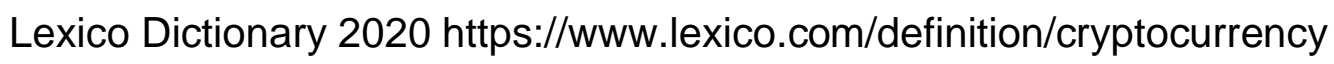
Lexico Dictionary 2020 Cryptocurrency https://www.lexico.com/definition/ cryptocurrency accessed 20 October 2020

Library of Congress 2020 https://www.loc.gov/law/help/cryptocurrency/ world-survey.php

Library of Congress 2020 Regulation of Cryptocurrency around the World https://www.loc.gov/law/help/cryptocurrency/world-survey.php accessed 22 October 2020

Malmo 2015 https://motherboard.vice.com/en_us/article/ae3p7e/bitcoin-isunsustainable

Malmo C 2015 Bitcoin is Unsustainable https://motherboard.vice.com/en_us/article/ae3p7e/bitcoin-isunsustainable accessed 22 November 2020

Nakamoto 2008 https://bitcoin.org/bitcoin.pdf Nakamoto S 2008 Bitcoin: A Peer-to-Peer Electronic Cash System https://bitcoin.org/bitcoin.pdf accessed 14 October 2020

National Treasury $2020 \mathrm{https}: / /$ perma.cc/B3D8-NPYS

National Treasury 2014 User Alert - Monitoring of Virtual Currencies https://perma.cc/B3D8-NPYS accessed 23 October 2020

Pilarowski and Yue 2017 http://www.pillarlegalpc.com/en/legalupdates/wpcontent/uploads/2020/08/PL-China-Regulation-Watch-Cryptocurrency2017-09-22.pdf

Pilarowski G and Yue L 2017 China Bans Initial Coin Offerings and Cryptocurrency Trading Platforms http://www.pillarlegalpc.com/en/ legalupdates/wp-content/uploads/2020/08/PL-China-Regulation-WatchCryptocurrency-2017-09-22.pdf accessed 15 October 2020

Polansek 2016 https://www.reuters.com/article/us-cme-group-bitcoinidUSKCNOXT1G1

Polansek T 2016 CME, ICE Prepare Pricing Data that could Boost Bitcoin https://www.reuters.com/article/us-cme-group-bitcoin-idUSKCNOXT1G1 accessed 20 October 2020 
Proshare 2019 https://www.proshareng.com/news/\%20BLOCKCHAIN\%20\&\% 20CRYPTOS/ Cryptocurrency-Ban-and-its-Economic-Implications/56279

Proshare 2019 Cryptocurrency Ban and its Economic Implications https://www.proshareng.com/news/\%20BLOCKCHAIN\%20\&\%20CRYPTOS/Crypt ocurrency-Ban-and-its-Economic-Implications/56279 accessed 20 October 2020

Redman 2020 https://news.bitcoin.com/altcoins-why-over-5000

Redman J 2020 What are Altcoins and Why are There Over 5,000 of Them? https://news.bitcoin.com/altcoins-why-over-5000 accessed 17 March 2021

Richards 2019 https://searchsecurity.techtarget.com/definition/crypto graphy

Richards K 2019 Cryptography https://searchsecurity.techtarget.com/ definition/cryptography accessed 17 October 2020

Rooney 2018 https://www.cnbc.com/2018/03/15/peter-thiel-is-betting-onbitcoin-to-be-the-online-equivalent-to-gold.html

Rooney K 2018 Peter Thiel is Betting on Bitcoin Because One Cryptocurrency Will Become the Online Equivalent to Gold https://www.cnbc.com/2018/03/15/peter-thiel-is-betting-on-bitcoin-to-bethe-online-equivalent-to-gold.html accessed 20 October 2020

Sagewriters 2019 https://btc.ng/bitcoin-guide/google-trends-lagos-nigeriatop-city-and-country-searches-for-bitcoin

Sagewriters 2019 Google Trends: Lagos, Nigeria Top City and Country Searches for Bitcoin https://btc.ng/bitcoin-guide/google-trends-lagosnigeria-top-city-and-country-searches-for-bitcoin accessed 20 October 2020

SARB 2021 https://www.resbank.co.za/en/home/quick-links/frequentlyasked-questions

South African Reserve Bank 2021 Do Any Compliance Requirements or Exchange Controls Apply to Crypto Assets? https://www.resbank.co.za/en/home/quick-links/frequently-askedquestions accessed 24 February 2021

SARS 2018 http://www.sars.gov.za/Media/MediaReleases/Pages/6-April2018---SARS-stance-on-the-tax-treatment-of-cryptocurrencies-.aspx South African Revenue Service 2018 Press Release: SARS'S Stance on the Tax Treatment of Cryptocurrencies http://www.sars.gov.za/ Media/MediaReleases/Pages/6-April-2018---SARS-stance-on-the-taxtreatment-of-cryptocurrencies-.aspx accessed 20 October 2020 
SEC $2017 \quad$ http://sec.gov.ng/public-notice-on-investments-in-crypto currencies-and-other-virtual-or-digital-currencies

Securities and Exchange Commission 2017 Public Notice on Investments in Cryptocurrencies and Other Virtual or Digital Currencies http://sec.gov.ng/public-notice-on-investments-in-cryptocurrencies-andother-virtual-or-digital-currencies accessed 20 October 2020

SEC 2020 https://sec.gov.ng/statement-on-digital-assets-and-theirclassification-and-treatment

Securities and Exchange Commission 2020 Statement on Digital Assets and their Classification and Treatment https://sec.gov.ng/statement-ondigital-assets-and-their-classification-and-treatment accessed 20 October 2020

Telegraph Reporters 2018 http://www.telegraph.co.uk/technology/ 0/cryptocurrency

Telegraph Reporters 2018 What is Cryptocurrency, How Does it Work and What are the Uses? http://www.telegraph.co.uk/technology/ 0/cryptocurrency accessed 20 October 2020

World Population Review 2021 https://worldpopulationreview.com/countryrankings/richest-african-countries

World Population Review 2021 Richest African Countries 2021 https://worldpopulationreview.com/country-rankings/richest-africancountries accessed 20 October 2020

Xie $2019 \quad$ https://medium.com/datadriveninvestor/4-types-of-crypto currencies-a-framework-to-think-about-cryptoassets-5cf2670fa1d7

Xie A 20194 Types of Cryptocurrencies - A Framework to Think about Cryptoassets https://medium.com/datadriveninvestor/4-types-of-crypto currencies-a-framework-to-think-about-cryptoassets-5cf2670fa1d7 accessed 10 October 2020

Xu 2018 http://www.scmp.com/business/banking-finance/article/2132009/ china-stamp-out-cryptocurrency-trading-completely-ban

Xu X 2018 China to Stamp out Cryptocurrency Trading Completely with Ban on Foreign Platforms http://www.scmp.com/business/bankingfinance/article/2132009/china-stamp-out-cryptocurrency-tradingcompletely-ban accessed 20 October 2020

Young $2020 \quad$ https://www.forbes.com/sites/youngjoseph/2020/06/10/ donald-trump-said-bitcoin-is-based-on-thin-air-but-wall-street-is-buying-enmasse/\#407a0a4b4d27

Young J 2020 Donald Trump Said Bitcoin is Based on "Thin Air," but Wall Street is Buying en Masse https://www.forbes.com/sites/young 
joseph/2020/06/10/donald-trump-said-bitcoin-is-based-on-thin-air-but-wallstreet-is-buying-en-masse/\#407a0a4b4d27 accessed 15 September 2020

\section{List of Abbreviations}

\begin{tabular}{|c|c|}
\hline CAR WG & Crypto Assets Regulatory Working Group \\
\hline CBN & Central Bank of Nigeria \\
\hline CFR & Code of Federal Regulations \\
\hline CFTC & Commodities Futures Trading Commission \\
\hline DMBs & deposit money banks \\
\hline EBA & European Banking Authority \\
\hline EIOPA & $\begin{array}{l}\text { European Insurance and Occupational } \\
\text { Pensions Authority }\end{array}$ \\
\hline ESMA & European Securities and Markets Authority \\
\hline EU & European Union \\
\hline FIC & Financial Intelligence Centre \\
\hline FinCEN & Financial Crimes Enforcement Network \\
\hline Fintech/FinTech & Financial technology \\
\hline $\mathrm{ICO}$ & initial coin offering \\
\hline IFWG & Intergovernmental Fintech Working Group \\
\hline IMF & International Monetary Fund \\
\hline IBER & $\begin{array}{l}\text { International Business and Economics } \\
\text { Research Journal }\end{array}$ \\
\hline IOSCO & $\begin{array}{l}\text { International Organisation of Securities } \\
\text { Commissions }\end{array}$ \\
\hline IRS & Inland Revenue Services \\
\hline JIM & Journal of Innovation Management \\
\hline J Appl Logic & Journal of Applied Logic \\
\hline J Syst Integrat & Journal of Systems Integration \\
\hline LFN & Laws of the Federation of Nigeria \\
\hline MBELR & $\begin{array}{l}\text { Michigan Business and Entrepreneurial Law } \\
\text { Review }\end{array}$ \\
\hline NBFls & non-bank financial institutions \\
\hline NT & National Treasury \\
\hline OFls & other financial institutions \\
\hline RSA & Republic of South Africa \\
\hline RTM & Research-Technology Management \\
\hline SARB & South African Reserve Bank \\
\hline SARS & South Africa Revenue Service \\
\hline SEC & Securities and Exchange Commission \\
\hline U Miami Int'I \& Comp & $\begin{array}{l}\text { University of Miami International and } \\
\text { Comparative Law Review }\end{array}$ \\
\hline Js & United States of America \\
\hline
\end{tabular}


USSEC

United States Securities and Exchange Commission

VAT Value Added Tax 